\title{
Primary care
}

\section{Blood pressure control by home monitoring: meta-analysis of randomised trials}

\author{
Francesco P Cappuccio, Sally M Kerry, Lindsay Forbes, Anna Donald
}

\begin{abstract}
Objective To determine the effect of home blood pressure monitoring on blood pressure levels and proportion of people with essential hypertension achieving targets.

Design Meta-analysis of 18 randomised controlled trials. Participants 1359 people with essential hypertension allocated to home blood pressure monitoring and 1355 allocated to the "control" group seen in the healthcare system for 2-36 months. Main outcome measures Differences in systolic (13 studies), diastolic (16 studies), or mean (3 studies) blood pressures, and proportion of patients achieving targets (6 studies), between intervention and control groups.

Results Systolic blood pressure was lower in people with hypertension who had home blood pressure monitoring than in those who had standard blood pressure monitoring in the healthcare system (standardised mean difference 4.2 (95\% confidence interval 1.5 to 6.9) $\mathrm{mm} \mathrm{Hg}$ ), diastolic blood pressure was lower by 2.4 (1.2 to 3.5$) \mathrm{mm} \mathrm{Hg}$, and mean blood pressure was lower by 4.4 (2.0 to 6.8$) \mathrm{mm} \mathrm{Hg}$. The relative risk of blood pressure above predetermined targets was lower in people with home blood pressure monitoring (risk ratio $0.90,0.80$ to 1.00 ). When publication bias was allowed for, the differences were attenuated: 2.2 ( -0.9 to 5.3$) \mathrm{mm} \mathrm{Hg}$ for systolic blood pressure and 1.9 (0.6 to 3.2) $\mathrm{mm} \mathrm{Hg}$ for diastolic blood pressure. Conclusions Blood pressure control in people with hypertension (assessed in the clinic) and the proportion achieving targets are increased when home blood pressure monitoring is used rather than standard blood pressure monitoring in the healthcare system. The reasons for this are not clear. The difference in blood pressure control between the two methods is small but likely to contribute to an important reduction in vascular complications in the hypertensive population.
\end{abstract}

\section{Introduction}

High blood pressure is one of the most readily preventable causes of stroke and other cardiovascular complications. ${ }^{1-4}$ It can be easily detected, and most cases have no underlying detectable cause; the most effective way to reduce the associated risk is to reduce the blood pressure. Unlike many other common, chronic conditions, we have very effective ways of treating high blood pressure and we have clear evidence of the benefits of such interventions. ${ }^{1}$ However, despite a great deal of time and effort, hypertension is still underdiagnosed and undertreated. ${ }^{5}$ Furthermore, losses to follow up are high and are responsible for avoidable vascular deaths. ${ }^{6}$
Blood pressure is usually measured and monitored in the healthcare system by doctors or nurses in hospital outpatient departments and, increasingly, in primary care settings. New electronic devices have been introduced and validated in the clinical setting to replace the mercury sphygmomanometer and to overcome the large variations in measurement due to variability between observers. Ambulatory blood pressure monitoring is also being used more often to assess individuals' blood pressures outside the clinical setting.

Measuring blood pressure at home is becoming increasingly popular with both doctors and patients. ${ }^{78}$ Some national and international guidelines also recommend home monitoring in certain circumstances. ${ }^{9}$ A recent qualitative review of the role of home blood pressure measurement in managing hypertension concluded that no evidence exists as to whether home monitoring leads to better control of high blood pressure. ${ }^{10}$

We reviewed the literature on home blood pressure monitoring and did a meta-analysis of the effect of home monitoring on blood pressure levels and the control of hypertension in randomised trials that compared home or "self" blood pressure monitoring and usual blood pressure monitoring in the healthcare system.

\section{Methods}

Identification and selection of trials

To identify published trials that met the inclusion criteria we searched Medline (1966 to January 2003) and Embase (1980 to January 2003) for randomised controlled trials of home or self blood pressure monitoring in people with high blood pressure (see appendix A on bmj.com for strategy). We also searched the Cochrane Database of Systematic Reviews, the Database of Abstracts of Clinical Effectiveness, the Health Technology Assessment Database, the NHS Economic Evaluation Database, the TRIP database, and the websites of the Centre for Reviews and Dissemination and the Agency for Healthcare Research and Quality for reviews of blood pressure monitoring studies. Finally, we examined reference lists of the relevant reviews and all identified studies and reviewed the cited literature. We extended the search to all languages.

We included studies in which the intervention under test was at least one measurement of blood pressure at home by study participants or their family members, whether the result was recorded by the participant or transmitted to a healthcare provider. ${ }^{11-31}$ We excluded studies that were not randomised con-

Appendices A-D are on bmj.com 


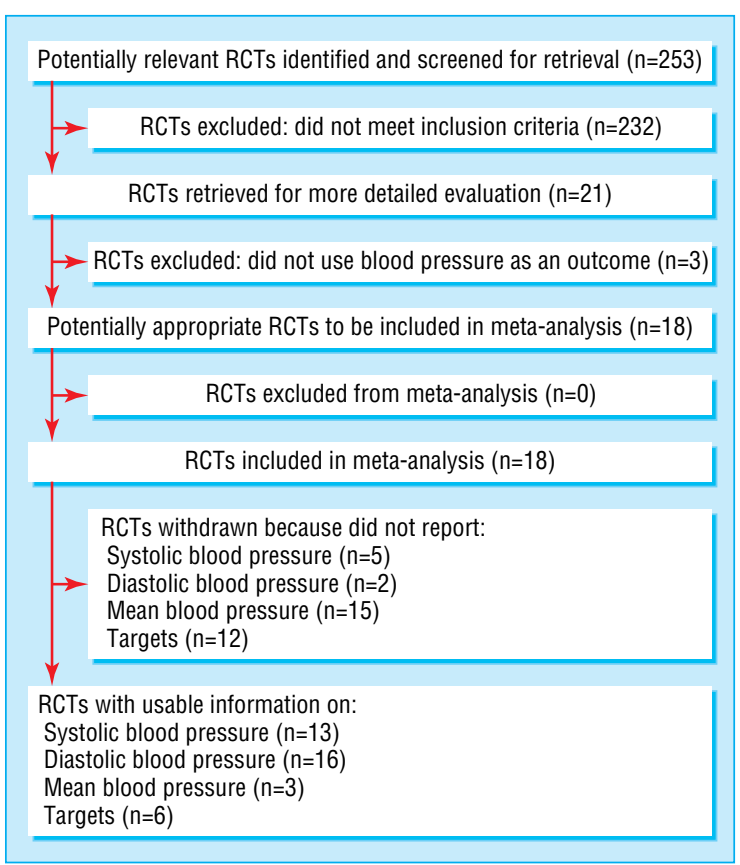

Fig 1 QUORUM statement flow diagram. RTC=randomised controlled trial

trolled trials and those that used "ambulatory" blood pressure monitoring rather than "home" or "self" blood pressure monitoring. When several publications reported aspects of the same study, we chose only one paper to represent the trial data on blood pressure control or on achievement of hypertension targets. Where endpoints were presented at different time points-for example, Earp et al and Stahl et al with endpoints at one and two years of follow up ${ }^{17}{ }^{19}$-we repeated analyses with the alternative time point.

We extracted data from text, tables, and graphs. Two reviewers (SMK and LF) independently examined the data. Differences about inclusion of studies and interpretation of data were resolved by arbitration (FPC), and consensus was reached after discussion. We found 253 references. Twenty one studies met the inclusion criteria. ${ }^{11-31}$ We excluded three of these studies because they did not use blood pressure as an outcome measure ${ }^{11-13}$ (fig $1)$.

\section{Outcome measures}

We assessed change in blood pressure (systolic, diastolic, and mean) between intervention and control arms as mean (SD) and change in the proportion of people with blood pressure above target (see appendix B on bmj.com for methods of assessment of outcome). We used target blood pressure as defined in each paper (see appendix $\mathrm{C}$ on bmj.com for targets used in each study); older studies used diastolic blood pressure only (90 or 95 $\mathrm{mm} \mathrm{Hg}$ ), and others used systolic pressure of $140 \mathrm{~mm} \mathrm{Hg}$ and diastolic pressure of $90 \mathrm{~mm} \mathrm{Hg}$ (see appendices D1-D3 on bmj.com for detailed blood pressure values and effects in each study).

\section{Statistical analysis}

We used a random effects model (StataCorp, College Station, TX, USA) for the meta-analysis of the difference in change in systolic blood pressure, diastolic blood pressure, or mean arterial pressure. Where standard deviation of the change was not reported or could not be calculated from the $95 \%$ confidence interval, we estimated it. As the standard deviation of the change was approximately the same as the standard deviations of the initial and follow up blood pressures in studies in which these were reported, we estimated the standard deviation of the change as the average of the standard deviations of the initial and follow up pressures where only the standard deviation of the change was missing. If no standard deviations were reported then we used the average standard deviation for all the remaining studies. We used relative risk to estimate the effect of intervention on the percentage of patients with blood pressure above target at follow up.

We assessed potential publication bias by using a funnel plot and Egger's test. ${ }^{32}$ Publication bias is due to small negative studies failing to be accepted for publication, which then causes the funnel plot to display asymmetry. We recalculated the combined estimate after estimating from the asymmetry of the funnel plot the number of "missing" studies and their effect sizes and standard errors, a method known as "trim and fill." ${ }^{34}{ }^{34}$ We assessed heterogeneity between trials by using the $\chi^{2}$ test.

\section{Results}

We identified 18 randomised controlled trials that compared blood pressure control or the proportion of people with blood pressure above target. The table shows the characteristics of the analysed trials. Six were based in hospital outpatient clinics, ${ }^{141921222531}$ eight in communities and general practices, ${ }^{16} 18232426-29$ and four in mixed settings. ${ }^{15} 172030$ Treatment in the "control" group was mainly "usual" or "standard"

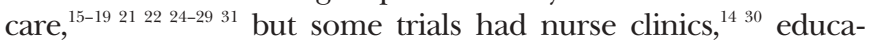
tional interventions, ${ }^{20}$ or flagged medical records. ${ }^{23}$ Trials used different methods of home or self blood pressure monitoring. In total, 1359 people were randomised to home or self blood pressure monitoring and 1355 to a control group of blood pressure monitoring by health professionals in clinical settings. Two trials used a factorial design, ${ }^{16}{ }^{18}$ four had more than two randomised groups, ${ }^{17} 192029$ and one was randomised in clusters. ${ }^{23}$ Only in eight trials was outcome assessment stated to have been blind, ${ }^{14-1624252931}$ and only in nine was randomisation concealed. $^{15-18} 2021242931$ The duration of the intervention varied between two months ${ }^{31}$ and 36 months. ${ }^{19}$

\section{Systolic blood pressure}

Thirteen studies reported systolic blood pressure at follow up and baseline or the change from baseline (see appendix D1 on bmj.com), but only five of these studies reported full data on means and the standard deviation of the difference. For the remaining seven studies we estimated standard deviations. The overall effect of intervention was 4.2 (95\% confidence interval 1.5 to 6.9$) \mathrm{mm} \mathrm{Hg}$, with highly significant heterogeneity between studies $(\mathrm{P}<0.001)$ (fig 2, top panel). The funnel plot showed some asymmetry, and Egger's test for publication bias was significant $(\mathrm{P}=0.038)$ (fig 3, top panel). The trim and fill method estimated three missing studies and gave a revised estimate of 2.2 ( -0.9 to 5.3$) \mathrm{mm} \mathrm{Hg}$.

\section{Diastolic blood pressure}

Sixteen studies reported diastolic blood pressure at follow up and baseline or the change from baseline (see appendix D2 on bmj.com), but only eight of these studies reported full data on means and the standard deviation of the difference. For the remaining eight studies we estimated standard deviations. One study had multiple endpoints. ${ }^{19}$ We included results from the one year endpoint. Use of the two year endpoint did not make an important difference to the results (2.2 (1.0 to 3.3) $\mathrm{mm} \mathrm{Hg}$ ). The overall effect of intervention was 2.4 (1.2 to 3.5$) \mathrm{mm} \mathrm{Hg}$, with significant heterogeneity between studies $(\mathrm{P}=0.014)$ (fig 2 , middle panel). The funnel plot showed some asymmetry (fig 3, bottom 
Characteristics of trials included in meta-analysis of home or self blood pressure monitoring

\begin{tabular}{|c|c|c|c|c|c|c|}
\hline Author and country & Setting & Age group (years) & Definition of hypertension & $\begin{array}{l}\text { Length of } \\
\text { intervention } \\
\text { (months) }\end{array}$ & Intervention group & Control group \\
\hline $\begin{array}{l}\text { Carnahan } 1975, \\
\text { USA }^{14}\end{array}$ & Hospital outpatient & Not stated & $\mathrm{DBP}>90 \mathrm{~mm} \mathrm{Hg}$ & 6 & $\begin{array}{l}\text { Home BP self recorded twice } \\
\text { daily }\end{array}$ & Nurse clinic \\
\hline $\begin{array}{l}\text { Haynes 1976, } \\
\text { Canada }^{15}\end{array}$ & Workplace & Not stated & $\mathrm{DBP} \geq 90 \mathrm{~mm} \mathrm{Hg}$ & 6 & $\begin{array}{l}\text { Daily BP self recorded on } \\
\text { chart }\end{array}$ & "Usual care" \\
\hline $\begin{array}{l}\text { Johnson } 1978, \\
\text { Canada }^{16}\end{array}$ & Community & $35-65$ & $\begin{array}{l}\text { On BP treatment at baseline } \\
\text { and } D B P \geq 95 \mathrm{~mm} \mathrm{Hg}\end{array}$ & 6 & $\begin{array}{l}\text { Daily BP self recorded on } \\
\text { chart }\end{array}$ & Home visits or "usual care" \\
\hline Earp $1982^{17}$ & $\begin{array}{l}\text { Hospital outpatient and } \\
\text { general practice }\end{array}$ & Not stated & Not stated & 18 & $\begin{array}{l}\text { Daily or twice weekly BP by } \\
\text { family member }\end{array}$ & Home visits \\
\hline $\begin{array}{l}\text { Pierce 1984, } \\
\text { Australia }^{18}\end{array}$ & General practice & $<70$ & $\begin{array}{l}\text { SBP }>160 \mathrm{~mm} \mathrm{Hg} \text { or DBP } \\
>95 \mathrm{~mm} \mathrm{Hg}\end{array}$ & 6 & $\begin{array}{l}\text { Daily BP self recorded on } \\
\text { chart }\end{array}$ & $\begin{array}{l}\text { "Usual care" or health } \\
\text { education programme }\end{array}$ \\
\hline Stahl 1984, USA ${ }^{19}$ & Hospital outpatient & $16-70$ & $\begin{array}{l}3 \times D B P \geq 95 \mathrm{~mm} \mathrm{Hg} \text { if }>30 \\
\text { years; DBP }>90 \mathrm{~mm} \mathrm{Hg} \text { if } \\
16-30 \text { years; } 2 x \mathrm{DBP}>100 \mathrm{~mm} \\
\mathrm{Hg} ; \text { DBP }>120 \mathrm{~mm} \mathrm{Hg}\end{array}$ & 36 & $\begin{array}{l}\text { Daily BP self recorded at } \\
\text { home }\end{array}$ & "Standard care" \\
\hline Binstock 1988, USA ${ }^{20}$ & Not clear & Not stated & $\begin{array}{l}\text { "Documented" hypertension } \\
\text { on treatment }\end{array}$ & 9 & Home BP monitoring & Educational intervention \\
\hline Midanik 1991, USA ${ }^{21}$ & Hospital outpatient & Not stated & $\begin{array}{l}\text { SBP }<180 \mathrm{~mm} \mathrm{Hg} \text { and DBP } \\
90-99 \mathrm{~mm} \mathrm{Hg}\end{array}$ & 12 & $\begin{array}{l}\text { Twice weekly BP self recorded } \\
\text { at home }\end{array}$ & $\begin{array}{l}\text { Standard care (not measuring } \\
\text { BP at home) }\end{array}$ \\
\hline $\begin{array}{l}\text { Soghikian } 1992, \\
\text { USA }^{22}\end{array}$ & Hospital outpatient & Not stated & Not stated & 12 & $\begin{array}{l}\text { Twice weekly BP self recorded } \\
\text { at home }\end{array}$ & "Usual care" \\
\hline $\begin{array}{l}\text { Muhlhauser 1993, } \\
\text { Germany }{ }^{23}\end{array}$ & General practice & $30-60$ & $2 \times B P>160$ or $>95 \mathrm{~mm} \mathrm{Hg}$ & 18 & $\begin{array}{l}\text { Twice daily BP self recorded } \\
\text { at home }\end{array}$ & $\begin{array}{l}\text { "Usual care" with flagged } \\
\text { notes }\end{array}$ \\
\hline $\begin{array}{l}\text { Friedman } 1996, \\
\text { USA }^{24}\end{array}$ & Community & $\geq 60$ & $\begin{array}{l}\text { On BP treatment at baseline } \\
\text { and } S B P \geq 160 \text { or } D B P \geq 90 \\
m m ~ H g\end{array}$ & 6 & $\begin{array}{l}\text { Weekly BP self recorded at } \\
\text { home }\end{array}$ & Regular medical care \\
\hline $\begin{array}{l}\text { Zarnke 1997, } \\
\text { Canada }^{25}\end{array}$ & Hospital outpatient & $18-80$ & Not stated & 2 & $\begin{array}{l}\text { Twice daily BP self recorded } \\
\text { at home }\end{array}$ & Standard office based care \\
\hline $\begin{array}{l}\text { Bailey 1999, } \\
\text { Australia }^{26}\end{array}$ & General practice & Not stated & Not stated & 2 & $\begin{array}{l}\text { Twice daily BP self recorded } \\
\text { at home }\end{array}$ & "Usual care" \\
\hline Mehos 2000, USA ${ }^{27}$ & General practice & $\geq 35$ & $\begin{array}{l}\text { SBP } 140-179 \mathrm{~mm} \mathrm{Hg} \text { or DBP } \\
90-109 \mathrm{~mm} \mathrm{Hg}\end{array}$ & 6 & $\begin{array}{l}\text { Daily BP self recorded at } \\
\text { home }\end{array}$ & No home monitoring \\
\hline $\begin{array}{l}\text { Vetter } 2000 \\
\quad \text { Switzerland }\end{array}$ & General practice & $18-85$ & $\begin{array}{l}\text { SBP } 160-200 \text { and DBP } \\
95-115 \mathrm{~mm} \mathrm{Hg} \text { and losartan }\end{array}$ & 2 & $\begin{array}{l}\text { Twice daily BP self recorded } \\
\text { at home before and } 12 \text { hours } \\
\text { after treatment }\end{array}$ & Doctor's office \\
\hline Artinian 2001, USA ${ }^{29}$ & Community & Not stated & $\begin{array}{l}\mathrm{SBP} \geq 140 \text { or } \mathrm{DBP} \geq 90 \mathrm{~mm} \\
\mathrm{Hg} \text {; if diabetes or myocardial } \\
\text { infarction, } \mathrm{SBP} \geq 130 \text { or DBP } \\
\geq 85 \mathrm{~mm} \mathrm{Hg}\end{array}$ & 3 & $\begin{array}{l}\text { BP self recorded at home } \\
\text { three times a week }\end{array}$ & "Usual care" \\
\hline Broege 2001, USA ${ }^{30}$ & $\begin{array}{l}\text { Community and hospital } \\
\text { outpatient }\end{array}$ & $\geq 65$ & $\begin{array}{l}\text { SBP }>150 \text { and DBP }<90 \text { (on } \\
\text { treatment) or }>90 \mathrm{~mm} \mathrm{Hg} \\
\text { (not on treatment) }\end{array}$ & 3 & $\begin{array}{l}\text { BP self recorded at home } \\
\text { every other day (also monthly } \\
\text { clinic visits) }\end{array}$ & Fortnightly nurse clinic \\
\hline Rogers 2001, USA ${ }^{31}$ & Hospital outpatient & $\geq 18$ & $\begin{array}{l}\text { Between } \geq 130 \text { or } \geq 85 \mathrm{~mm} \mathrm{Hg} \\
\text { and } \geq 180 \text { or } \geq 110 \mathrm{~mm} \mathrm{Hg} \text {, } \\
\text { depending on complications }\end{array}$ & $2-7$ & $\begin{array}{l}\text { BP self recorded at home } \\
\text { three times a week }\end{array}$ & Usual outpatient care \\
\hline
\end{tabular}

$\mathrm{BP}=$ blood pressure; $\mathrm{DBP}=$ diastolic blood pressure; $\mathrm{SBP}=$ systolic blood pressure.

panel) (Egger's test for publication bias, $\mathrm{P}=0.095)$. The trim and fill method estimated two missing studies and gave a revised estimate of 1.9 (0.6 to 3.2$) \mathrm{mm} \mathrm{Hg}$.

\section{Mean arterial pressure}

Three studies reported mean arterial pressure, one of which did not report either systolic or diastolic blood pressure. ${ }^{25}$ All studies reported change from baseline (see appendix D3 on bmj.com) with standard deviation of the difference. The overall effect was 4.4 (2.0 to 6.8$) \mathrm{mm} \mathrm{Hg}$, with no significant heterogeneity $(\mathrm{P}=0.319)$ (fig 2, bottom panel).

\section{Blood pressure above target}

Six studies reported the number of patients whose blood pressure was controlled at follow up. Different definitions of blood pressure control were used (see appendix $\mathrm{C}$ on bmj.com). Two studies reported the outcome at more than one time point. The analysis reported here is for the one year outcome in both studies. The overall relative risk was 0.90 (0.80 to 1.00$)$, with no significant heterogeneity between studies $(\mathrm{P}=0.34)$ (fig 4$)$. Inclusion of the two year outcomes for Earp ${ }^{17}$ and Stahl $^{19}$ slightly reduced the effect-relative risk 0.92 (0.83 to 1.04).

\section{Discussion}

\section{Main findings}

The meta-analysis of 18 randomised controlled clinical trials found that "self" blood pressure monitoring at home results in better blood pressure control and greater achievement of blood pressure targets than "usual" blood pressure monitoring in the healthcare system. The size of the difference is rather small from the clinical viewpoint: $2.2 / 1.9 \mathrm{~mm} \mathrm{Hg}$ (when allowing for publication bias), with $10 \%$ greater proportion on target. However, this may represent an adjunctive useful improvement in management of hypertension likely to contribute to a better outlook for cardiovascular events. The main inclusion criterion in the study was that participants had undertaken blood pressure monitoring at home either by themselves or with the aid of a family member. As this is the likely scenario for implementation in a population setting, the results of our meta-analysis could be applicable to the general population of people with mild to moderate essential hypertension. 


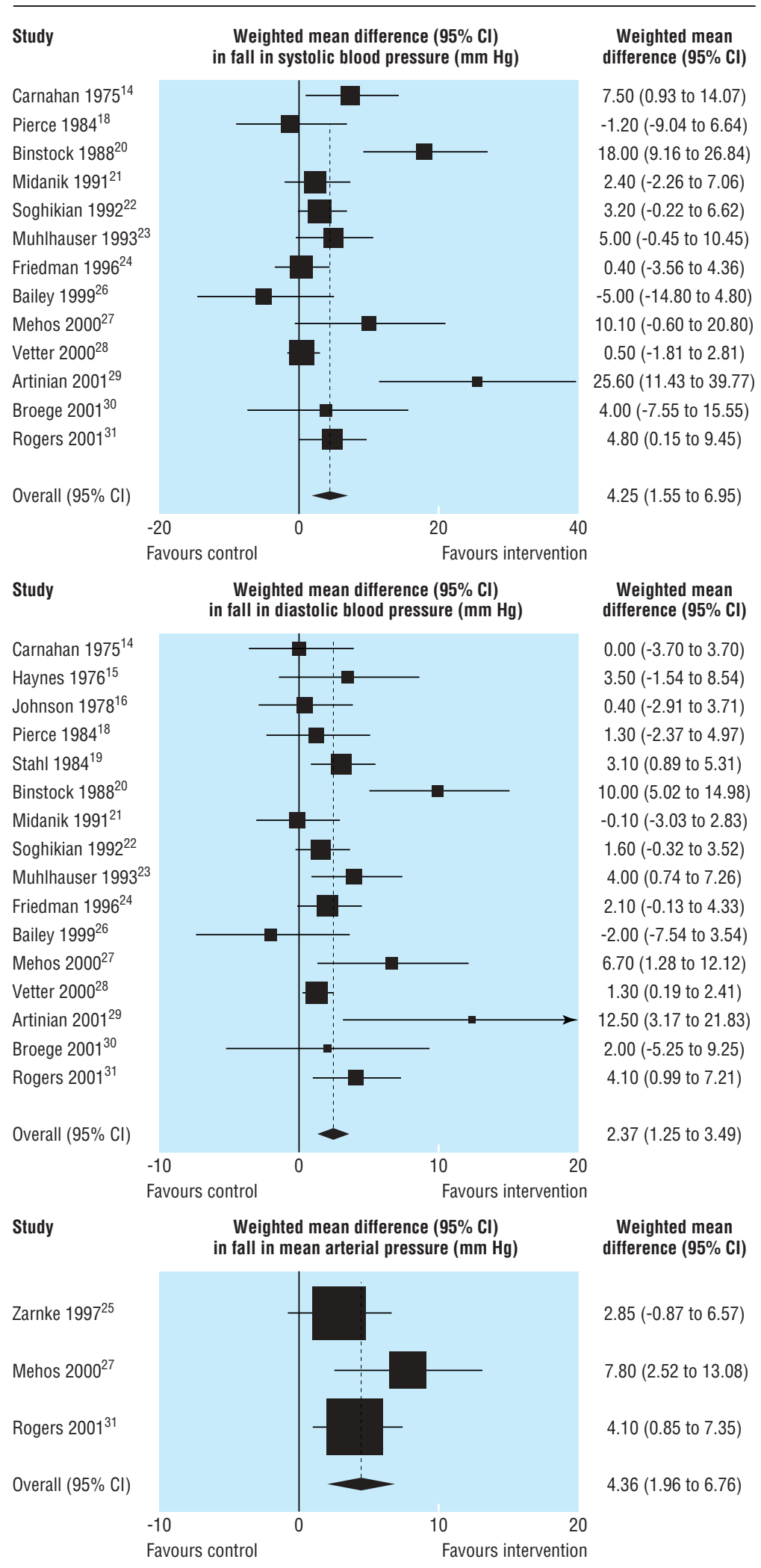

Fig 2 Standardised mean differences (95\% confidence interval) in systolic (top), diastolic (middle), and mean (bottom) blood pressures achieved in people monitoring blood pressure at home compared with people whose blood pressure was monitored by health professionals in clinical settings

\section{Limitations of the study}

The studies included in the quantitative review were done in a variety of settings, with different methods, using different criteria and different comparative groups. Any potentially consistent effect might have been underestimated. Furthermore, despite our adjustments with statistical methods, the likelihood of publi- cation bias cannot be excluded. The analysis of hypertension targets may not be easily extrapolated to today's recommended targets of national and international guidelines, because different thresholds were used in different studies. 

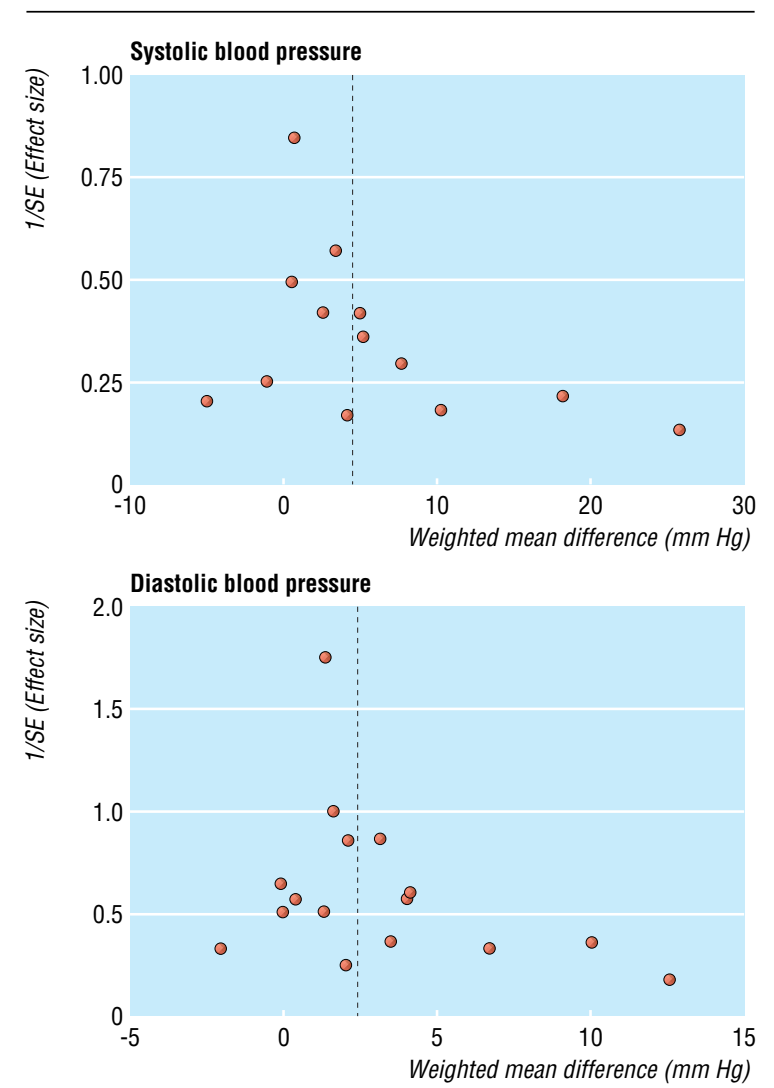

Fig 3 Funnel plots for systolic and diastolic blood pressure

\section{Implications}

Home blood pressure monitoring has been shown to be feasible; acceptable to patients, nurses, and doctors in general practice; and more suitable for the screening of "white coat" hypertension than ambulatory blood pressure monitoring. ${ }^{35}{ }^{36}$ The white coat effect is important in the diagnosis and treatment of hypertension, even in a primary care setting, and is not a research artefact. ${ }^{37}$ Either repeated measurements by health professionals or ambulatory or home measurements may substantially improve estimates of blood pressure and management and control of hypertension. Home blood pressure measurements are the most acceptable method to patients and are preferred to either readings in the surgery or ambulatory monitoring. ${ }^{38} 39$ They provide accurate blood pressure measurements in most patients, although some patients of low educational level may have poor reporting accuracy. ${ }^{39}$ Finally, blood pressure monitoring at home might help to improve awareness and concordance, and thus overall effective management.

\section{What is already known on this topic}

Blood pressure is usually measured and monitored in the healthcare system by health professionals

With the introduction and validation of new electronic devices, self blood pressure monitoring at home is becoming increasingly popular

No evidence exists as to whether use of home monitoring is associated with better control of high blood pressure

\section{What this study adds}

Patients who monitor their blood pressure at home have a lower "clinic" blood pressure than those whose blood pressure is monitored in the healthcare system

A greater proportion of them also achieve blood pressure targets when assessed in the clinic

After we submitted our manuscript, a multicentre randomised trial was published that compared the use of blood pressure measurements taken in the physician's office and at home and the potential impact on the management of hypertension. ${ }^{40}$ After a year, home blood pressure levels were lower than office blood pressures. Adjustment of antihypertensive treatment on the basis of home blood pressure instead of office blood pressure led to less intensive drug treatment and lower costs. Less good blood pressure control as judged by office blood pressure targets was obviously recorded. At variance with this trial, our results indicate that the practice of monitoring blood pressure "at home" leads to a better control of blood pressure "in the clinic." Nevertheless, the results of our systematic review and of the latest trial highlight the need for further evidence from prospective studies of outcome to inform potential modifications of treatment guidelines.

\section{Conclusions}

We conclude that blood pressure monitoring by patients at home is associated with better blood pressure values and improved control of hypertension than usual blood pressure monitoring in the healthcare system. As home blood pressure monitoring is now feasible, acceptable to patients, and reliable for most of them, ${ }^{41}$ it could be considered as a useful, though adjunctive, practice to involve patients more closely in the management of their own blood pressure and help to manage their hypertension more effectively.

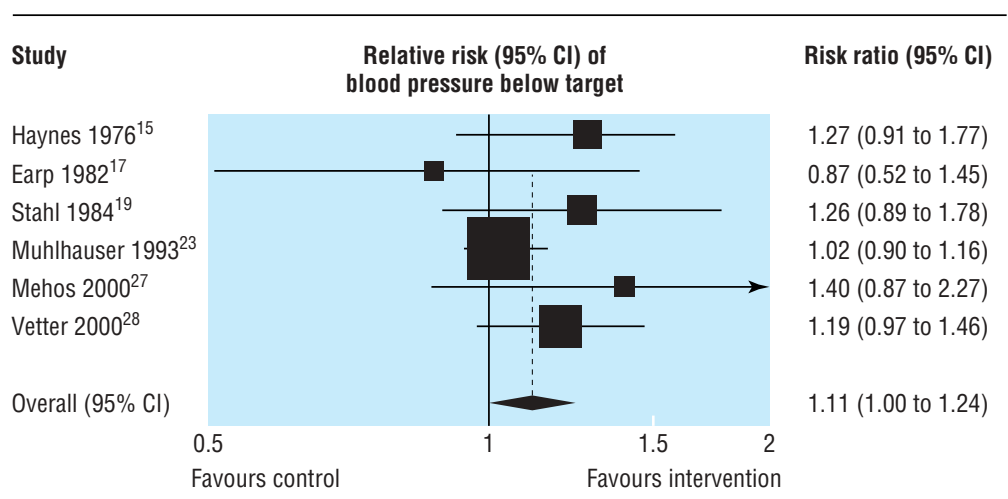

Fig 4 Standardised relative risk of blood pressure above target in people monitoring blood pressure at home compared with people whose blood pressure was monitored by health professionals in clinical settings 
FPC is a member of the St George's Cardiovascular Research Group. Contributors: FPC, LF, and AD conceived the idea, set the objectives, and contributed to design and interpretation. LF ran the searches. SMK and LF abstracted the data, consulting FPC when necessary. SMK did the statistical analysis. FPC drafted the paper, and all authors reviewed it. FPC is the guarantor.

Funding: Bazian Ltd was supported, in part, by an educational grant from Bristol-Myers Squibb.

Competing interests: Bazian Ltd is an independent company that specialises in evidence based reviews and training. It has a policy of strict scientific integrity and does not accept contracts that threaten impartiality when assessing and reviewing research. Bazian Ltd provides managing editorship to publications of the BMJ Publishing Group.

Ethical approval: Not needed.

1 Collins R, Peto R, MacMahon S, Hebert P, Fiebach NH, Eberlein KA, et al. Blood pressure, stroke and coronary heart disease. II. Short term reductions in blood pressure: overview of randomised drug trials in their epidemiological context. Lance 1990:335:827-38.

2 MacMahon S, Peto R, Cutler J, Collins R, Sorlie P, Neaton J, et al. Blood pressure, stroke and coronary heart disease. I. Effect of prolonged differences in blood pressure: evidence from nine prospective observational studies corrected for the regression dilution bias. Lancet 1990;335:765-74.

3 Prospective Studies Collaboration. Age-specific relevance of usual blood pressure to vascular mortality: a meta-analysis of individual data for one million adults in 61 prospective studies. Lancet 2002;360:1903-13.

4 Prospective Studies Collaboration. Cholesterol, diastolic blood pressure, and stroke: 13,000 strokes in 450,000 people in 45 prospective cohorts. Lancet 1995;346:1647-53.

5 Primatesta P, Brookes M, Poulter NR. Improved hypertension management and control: results from the health survey for England 1998. Hypertension 2001;38:827-32.

6 Du X, Cruickshank K, McNamee R, Saraee M, Sourbutts J, Summers A, et al Case-control study of stroke and the quality of hypertension control in north west England. BMJ 1997;314:272-6.

7 Yarows SA, Staessen JA. How to use home blood pressure monitors in clinical practice Am J Hypertens 2002;15:93-6.

8 Yarows SA, Julius S, Pickering TG. Home blood pressure monitoring. Arch Intern Med 2000;160:1251-7.

9 Chobanian AV, Bakris GL, Black HR, Cushman WC, Green LA, Izzo JL Jr, et al. The seventh report of the joint national committee on prevention, detection, evaluation, and treatment of high blood pressure: the JNC 7 report. JAMA 2003;289:2560-71.

10 Rickerby J. The role of home blood pressure measurement in managing hypertension: an evidence-based review. J Hum Hypertens 2002;16:469-72.

11 Cartwright W, Dalton KJ, Swindells H, Rushant S, Mooney P. Objective measurement of anxiety in hypertensive pregnant women managed in hospital and in the community. Br J Obstet Gynaecol 1992;99:182-5.

12 Glanz K, Kirscht JP, Rosenstock IM. Linking research and practice in patient education for hypertension: patient responses to four educational interventions. Med Care 1981;19:141-52.

13 Ross-McGill H, Hewison J, Hirst J, Dowswell T, Holt A, Brunskill P, et al. Antenatal home blood pressure monitoring: a pilot randomised controlled trial. Br J Obstet Gynaecol 2000;107:217-21

14 Carnahan.JE, Nugent CA. The effects of self monitoring by patients on the control of hypertension. Am J Med Sci 1975;269:69-73.

15 Haynes RB, Sackett DL, Gibson ES, Taylor DW, Hackett BC, Roberts RS, et al. Improvement of medication compliance in uncontrolled hypertension. Lancet 1976;i:1265-8.

16 Johnson AL, Taylor DW, Sackett DL, Dunnett CW, Shimizu AG. Self-recording of blood pressure in the management of hypertension. CMAJ 1978;119:1034-9.

17 Earp JA, Ory MG, Strogatz DS. The effects of family involvement and practitioner home visits on the control of hypertension. Am J Public Health 1982;72:1146-54.

18 Pierce JP, Watson DS, Knights S, Gliddon T, Williams S, Watson R. A controlled trial of health education in the physician's office. Prev Med 1984;13:185-94

19 Stahl SM, Kelley CR, Neill PJ, Grim CE, Mamlin J. Effects of home blood pressure measurement on long-term BP control. Am J Public Health 1984;74:704-9.

20 Binstock ML, Franklin KL. A comparison of compliance techniques on the control of high blood pressure. Am J Hypertens 1988;1:192-4S.
21 Midanik LT, Resnick B, Hurley LB, Smith EJ, McCarthy M. Home blood pressure monitoring for mild hypertensives. Public Health Rep 1991;106:85-9.

22 Soghikian K, Casper SM, Fireman BH, Hunkeler EM, Hurley LB, Tekawa IS, et al. Home blood pressure monitoring: effect on use of medical services and medical care costs. Med Care 1992:30:855-65.

23 Muhlhauser I, Sawicki PT, Didjurgeit U, Jorgens V, Trampisch HJ, Berger M. Evaluation of a structured treatment and teaching programme on hypertension in general practice. Clin Exp Hypertens 1993;15:125-42.

24 Friedman RH, Kazis LE, Jette A, Smith MB, Stollerman J, Torgerson J, et al. A telecommunications system for monitoring and counseling patients with hypertension: impact on medication adherence and blood pressure control. Am J Hypertens 1996;9:285-92.

25 Zarnke KB, Feagan BG, Mahon JL, Feldman RD. A randomized study comparing a patient-directed hypertension management strategy with usual office-based care. AmJ Hypertens 1997;10:58-67.

26 Bailey B, Carney SL, Gillies AA, Smith AJ. Antihypertensive drug treatment: a comparison of usual care with self blood pressure measurement. J Hum Hypertens 1999;13:147-50.

27 Mehos BM, Saseen JJ, MacLaughlin EJ. Effect of pharmacist intervention and initiation of home blood pressure monitoring in patients with uncontrolled hypertension. Phar macotherapy 2000;20:1384-9.

28 Vetter W, Hess L, Brignoli R. Influence of self-measurement of blood pressure on the responder rate in hypertensive patients treated with losartan: results of the SVATCH study. J Hum Hypertens 2000;14:235-41.

29 Artinian NT, Washington OG, Templin TN. Effects of home telemonitoring and community-based monitoring on blood pressure control in urban African Americans: a pilot study. Heart Lung 2001;30:191-9.

30 Broege PA, James GD, Pickering TG. Management of hypertension in the elderly using home blood pressures. Blood Press Monit 2001;6:139-44.

31 Rogers MA, Small D, Buchan DA, Butch CA, Stewart CM, Krenzer BE, et al. Home monitoring service improves mean arterial pressure in patients with essential hypertension: a randomized, controlled trial. Ann Intern Med 2001;134:1024-32.

32 Egger M, Davey SG, Schneider M, Minder C. Bias in meta-analysis detected by a simple, graphical test. $B M J$ 1997;315:629-34.

33 Sutton AJ, Song F, Gilbody SM, Abrams KR. Modelling publication bias in meta-analysis: a review. Stat Methods Med Res 2000;9:421-45.

34 Sutton AJ, Duval SJ, Tweedie RL, Abrams KR, Jones DR. Empirical assessment of effect of publication bias on meta-analyses. BMJ 2000;320:1574-7.

35 Aylett M, Marples G, Jones K. Home blood pressure monitoring: its effect on the management of hypertension in general practice. Br J Gen Pract 1999;49:725-8.

36 Brueren MM, Schouten HJA, de Leeuw PW, van Montfrans GA, van Ree JW. A series of self-measurements by the patient is a reliable alternative to ambulatory blood pressure measurement. Br J Gen Pract 1998:48:1585-9.

37 Nordmann A, Frach B, Walker T, Martina B, Battegay E. Reliability of patients measuring blood pressure at home: prospective observational study. BMJ 1999;319:1172.

38 Little P, Barnett J, Barnsley L, Marjoram J, Fitzgerald-Barron A, Mant D. Comparison of agreement between different measures of blood pressure in primary care and daytime ambulatory blood pressure. BMJ 2002:325:254

39 Little P, Barnett J, Barnsley L, Marjoram J, Fitzgerald-Barron A, Mant D. Comparison of acceptability of and preferences for different methods of measuring blood pressure in primary care. BMJ 2002;325:258-9.

40 Staessen JA, Den Hond E, Celis H, Fagard R, Keary L, Vandenhoven G, et al. Antihypertensive treatment based on blood pressure measurement at home or in the physician's office. JAMA 2004;291:955-64.

41 Williams B, Poulter NR, Brown MJ, Davis M, McInnes GT, Potter JF, et al. Guidelines for management of hypertension: report of the fourth working party of the British Hypertension Society, 2004-BHS IV.J Hum Hypertens 2004;18:139-85.

(Accepted 1 February 2004)

doi $10.1136 /$ bmj.38121.684410.AE

Department of Community Health Sciences, St George's Hospital Medical School, London SW17 0RE

Francesco P Cappuccio professor of clinical epidemiology and primary care

Sally M Kerry senior lecturer in medical statistics

Bazian Ltd, London N1 1QP

Lindsay Forbes public health consultant

Anna Donald managing director

Correspondence to: F P Cappuccio f.cappuccio@sghms.ac.uk 